\title{
Local Superior Products in Agricultural Sector: A case study in Banggai Regency Indonesia
}

\author{
Nurhidayah Layoo ${ }^{1}$, Wahyudin Rahman ${ }^{2}$, Sutrisno K. Djawa ${ }^{3}$, \\ Nurmawati Mambuhu ${ }^{4}$, Moh. Gifari Sono ${ }^{5}$, Mustafa Abd Rahim ${ }^{6}$, Ratmi Rosilawati ${ }^{7}$, Lutfi Samaduri ${ }^{8}$, Winarto \\ Ramlan", Nuning Kurniasih $^{10}$ \\ ${ }_{1,2,3,4,5}$ Management Study Program, Economy and Business of Faculty, Muhammadiyah Luwuk \\ University, Luwuk, 94711, Indonesia \\ ${ }^{6,7,8,9}$ Agribusiness Study Program, Agriculture of Faculty, Muhammadiyah Universities \\ Luwuk, 94711, Indonesia \\ ${ }^{10}$ Faculty of Communication Sciences, Library and Information Science Program, Universitas Padjadjarany, Bandung, 45363, Indone- \\ sia \\ *Corresponding author E-mail: wahyu@unismuhluwuk.ac.id
}

\begin{abstract}
The optimization of LSP aims to increase employment opportunities, regional economic growth, Own-Source Revenue, as well as regional per capita income, and ultimately cut the poverty. To achieve so, the findings from the research are required to determine the LSP of Banggai Regency, set the priority scale from agriculture sectors based on the availability of raw material, market potential, human resource support, uniqueness, and economic contribution. The research used purposive sampling by selecting 15 SMEs sub-jects. The expert group consisted of 3 heads of division in Food Crops Horticulture and Plantation Department and 5 academics from Faculty of Agriculture. The researchers carried out the data collection by conducting in-depth interview to small business owners and FGD on the expert group. The result shows that the superior products of Banggai Regency are rice, corn, cassava, coconut, and banana products. The government should actively encourage the SMEs to prioritize the LSP of the coconut products. In addition, the SMEs empowerment lies in the aspects of human resource, production facilities and utilization of market potential.
\end{abstract}

Keywords: Local Superior Product, Agriculture Sector, Analytic Hierarchy Process

\section{Introduction}

To increase the competitiveness of Banggai Regency Indonesia, the government requires a policy that is able to encourage and cultivate the development of regional market potential into a real form. With such potential, the regency will be able to build the core competencies and optimize the resources owned in order to improve the local economic development.

The development of Local Superior Products (LSP) is a strategy that will effectively optimize the local resources. The selection of regional superior products might be based on the contribution of the goods-producing sector to the Gross Regional Domestic Product (GRDP). According to Banggai Regency GRDP data, two major sectors namely agriculture and fishery dominated the list from 2012 to 2015; however, the values continued to decline from year to year. The processing industries have reportedly topped the list in 2017 , contributing $26.12 \%$ to the government, with fishery and agriculture follow closely behind with $23.98 \%$ [1] [2] [3], [4], [5], [6], [7]

So far the GRDP criteria, production data, stakeholder opinion, and socio-cultural consideration are often taken into consideration in determining the priority scale of Local Superior Products development. However, then it is replaced with Analytic Hierarchy Process (AHP) due to the complex process of selecting the superior products. The complexity of LSP decision-making problem lies not only in the uncertainty or imperfection of the information, but also in the complex issues, in which many factors are involved. Saaty [8], the developer of a decision analysis method called AHP, explained that a complex problem can be described into groups and then is organized into a hierarchical structure, so that the problem will be more well-organized and structured [8].

With this method, the government can establish a program that will focus more to develop LSP in order to create more employment oportunities, improve the society living standards, lower the poverty rate, and encourage the economic growth. In addition, the optimization of LSP aims to increase employment opportunities, regional economic growth, Own-Source Revenue, as well as regional per capita income, and ultimately cut the poverty [9] [10] [11], [12], [13]. To achieve so, the findings from the research are required to determine the LSP of Banggai Regency, set the priority scale from agriculture sectors based on the availability of raw material, market potential, human resource support, uniqueness, and economic contribution.

\section{Method}

The population were all the stakeholders related to the LSP development in Banggai Regency Indonesia. The research used purposive sampling by selecting 15 SMEs subjects. The expert group consisted of 3 heads of division in Food Crops Horticulture and Plantation Department and 5 academics from Faculty of Agriculture. 
The secondary data included legislation, research results, GRDP data, population data, data on agricultural production, retrieved from Central Bureau of Statistics and other related institutions. The primary data was collected from the research sample. The researchers carried out the data collection by conducting in-depth interview to small business owners and FGD on the expert group. The data analysis methods used were AHP method was used to set the priority scale of Banggai Regency LSP from agriculture sectors, using five criteria as follows: raw material availability, market potential, Human Resource (HR) support, uniqueness, and economic contribution. It was supported by Expert Choice software [14] [15] [16]

\section{Result and Discussion}

The alternative products from the selected area are rice, corn, cassava, coconut, and banana due to several considerations: 1) the production volume is considerably high compared with other commodities, so it is possible that the raw materials will be available in sufficient quantities if processed into various semi or finished product. For example, rice is a commodity where the production exceeds the needs of Banggai Regency people. Therefore, this area has a food surplus and become a supplier for the surrounding area for decades. Meanwhile, from the BPS data recorded, Banggai Regency is the second largest the coconut producer in Central Sulawesi Province for several reasons as follows: 1) the variety has been cultivated for generations, 2) it can grow in all areas of Banggai Regency except in rice paddy, and 3) the availability of land encourages further development of the crop. According to the data of Horticulture and Plantation Department, Banggai Regency, there is only about $3,636.45$ ha or just $6.19 \%$ of a total land of 58,712.00 that has been utilized, meaning that there are still $55,075.55$ ha of land that can be utilized for the development of superior commodities.

Table 1: Types of commodity and production (in tons) of Plantation, Food Crops, and Holticulture in Banggai Regency Indonesia, 2016

\begin{tabular}{|l|c|r|r|}
\hline No & $\begin{array}{c}\text { Types of } \\
\text { Commodity }\end{array}$ & $\begin{array}{r}\text { Total harvested } \\
\text { area(ha) }\end{array}$ & Production(ton) \\
\hline $\mathbf{1}$ & Rice & 42.636 & $209.680,00$ \\
$\mathbf{2}$ & Corn & 6.188 .00 & 25.867 .00 \\
$\mathbf{3}$ & Cassava & 272.00 & 5.691 .00 \\
$\mathbf{4}$ & Coconut & 54.237 .1 & 43.995 .60 \\
$\mathbf{5}$ & Banana & 79.465 trees & 2.425 .10 \\
\hline
\end{tabular}

Source: [1] [2] [3]

The representation of hierarchy using AHP divides the structure into objective, criteria, and alternative in order. In making the model hierarchy, there are some things that need to be determined as follows:

Objective: Determine the LSP of Banggai Regency Indonesia in agricultural sector

Criteria : There are five criteria such as the availability of production facilities, market potential, HR support, uniqueness, and economic contribution

Alternative: There are five superior products (see figure1).

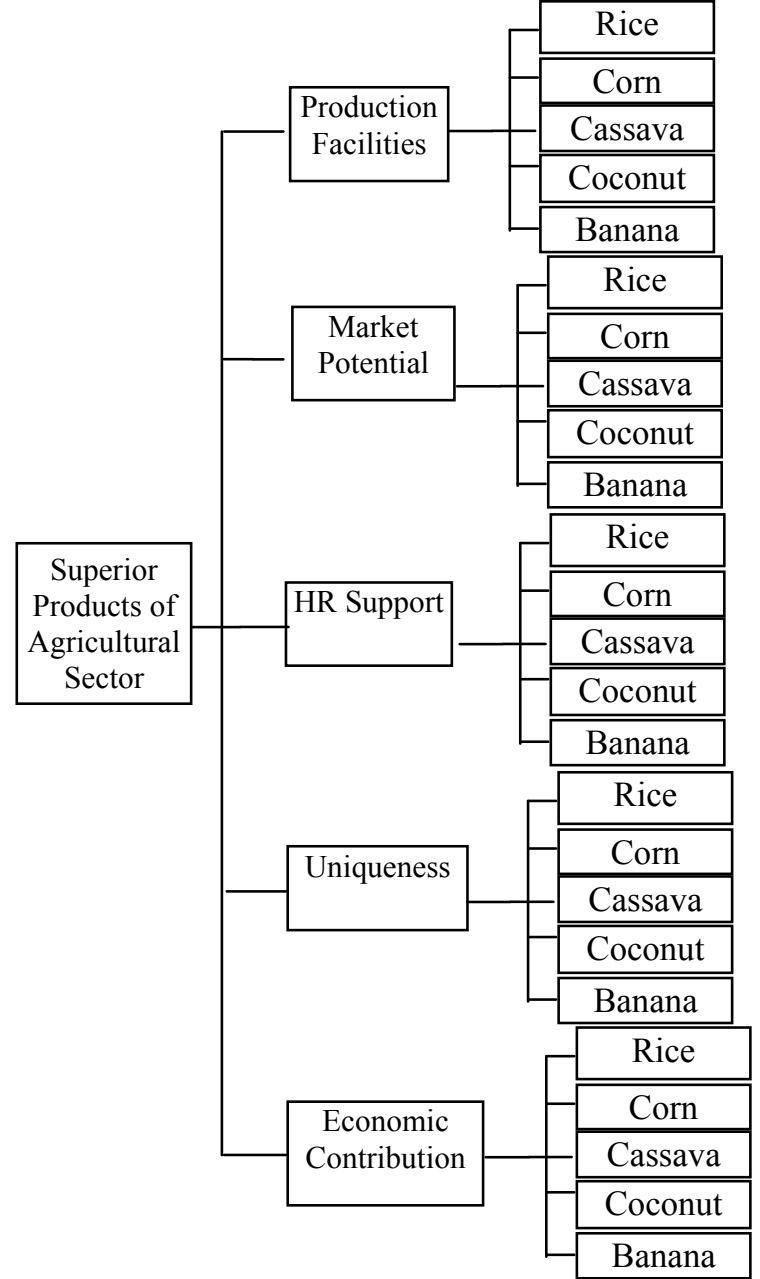

Fig.1: Criteria and Alternative of Superior Products of Agriculture SMEs

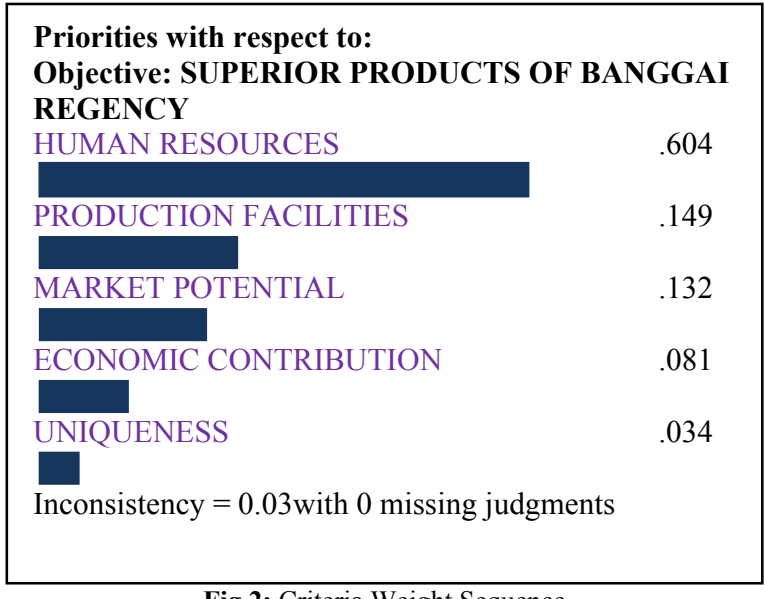

Fig.2: Criteria Weight Sequence

Human resource in agricultural sector including farmers and extension workers is regarded as the most important aspect in developing LSP. Farmers need to be encouraged to use better seeds, crop maintenance including fertilization and pest eradication, equipment and machinery, and post-harvest processing steps. The One Village One Product (OVOP) program should be encouraged in order to help farmers focusing on one commodity according to the potential of each subdistrict. Each village/urban village also needs at least 1 agricultural extension worker. However, this is not easy because the government regulation forces the agricultural extension workers to work in the regional level. As a result, the number of extension worker ratio is unbalanced where one extension worker must handle village/urban village. 
There are five key points that the government needs to focus in providing the production facilities. There needs to be an optimization of the land, for it has not been utilized effectively for the coconut cultivation. Moreover, it is necessary to provide and maintain a sufficient inventory of good seeds. The amount of pesticide used to eliminate agricultural pests need to be controlled to avoid the hazardous and harmful effects on human. To improve the farm productivity, it is also suggested that the government actively finds solutions to reduce the switch of employment from agricultural sector to the oil and gas industry. It is also important to focus in improving the technology of coconut output processing. To expand the market outside Banggai Regency, the government must cooperate with some coconut processing industries. The governments also have to enter the global market.

\begin{tabular}{|c|c|}
\hline \multicolumn{2}{|c|}{$\begin{array}{l}\text { Priorities with respect to: } \\
\text { Goal: Superior Products of Banggai Regency in Agricul- } \\
\text { tural Sector }\end{array}$} \\
\hline BANANA & .161 \\
\hline RICE & .125 \\
\hline CORN & .049 \\
\hline CASAVA & .049 \\
\hline
\end{tabular}

Fig. 3: LSP of agricultural sector-Based on the Availability of Production Facilities

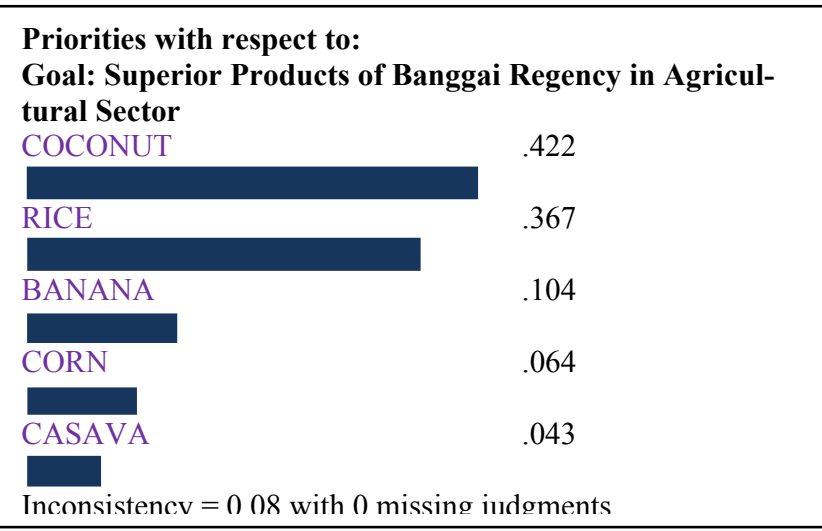

Fig. 4: LSP of agricultural sector-Based on Potential Market Criteria

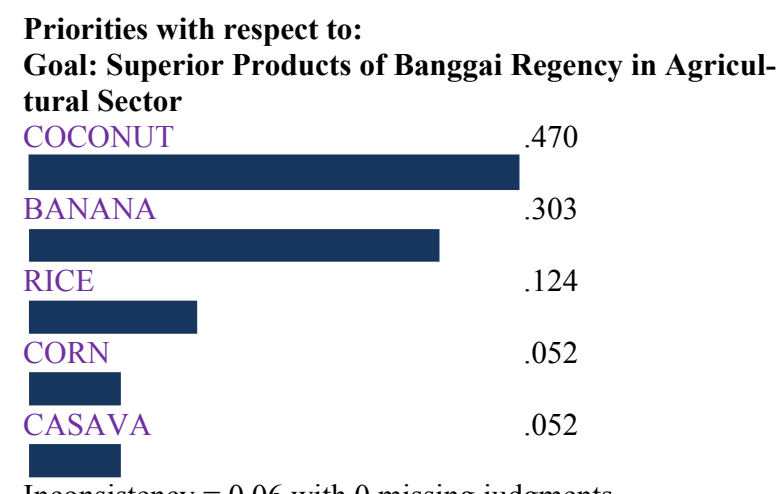

Inconsistency $=0.06$ with 0 missing judgments

Fig. 5: LSP of agricultural sector-Based on HR Support Criteria

Coconut is worth to be superior products due to the commodity high availability and the large market potential in Banggai Regency. This commodity is also always in high demand both in domes- tic and overseas market where the consumers buy it for family consumption or industry especially the young coconut and mature coconut. During Ramadan the demand for mature coconut and young coconut increases, while during the religious holidays the demand for young coconut leaves increases.

The high market demand for crude coconut oil also has led to the absorption of copra produced by farmers. In addition, coconut is also used by coconut milk processing industry. It has been known that coconut has various benefits and uses. Coconut shells, for example, are the raw materials of charcoal and are often used by artisans to create handicrafts. Coconut water is the main ingredient of nata de coco. Coir fibre made of tough fibers is used in car seats and mats manufacturer. Coconut trunks are sold and used as building material and furniture material. In fact, most of coconut trunksare sold in Java Island. The stiff midribs of coconut leaves are made into broom and sold by the SMEs. Based on the uniqueness criteria, banana was the most unique of all other commodities. Some unique types of banana in Banggai are Lowebanana and lady finger banana.

\begin{tabular}{lc}
\hline $\begin{array}{l}\text { Priorities with respect to: } \\
\text { Goal: Superior Products of Banggai Regency in Agricul- } \\
\text { tural Sector } \\
\text { BANANA }\end{array}$ \\
$\begin{array}{lc}\text { COCONUT } \\
\text { RICE }\end{array}$ \\
CASAVA \\
CORN \\
Inconsistency $=0.02$ with 0 missing judgments
\end{tabular}

Fig. 6: Local Superior Products of agricultural sector-Based on Uniqueness Criteria

$\begin{aligned} & \text { Priorities with respect to: } \\ & \text { Goal: Superior Products of Banggai Regency in Agricul- } \\ & \text { tural Sector } \\ & \text { COCONUT }\end{aligned}$
$\begin{array}{ll}\text { RICE } \\ \text { BANANA }\end{array}$
CORN
CASAVA
Inconsistency $=0.08$ with 0 missing judgments

Fig. 7: LSP of agricultural sector Based on Economic Contribution Criteria

The economic contribution factor included the involvement of human labors and the increase in the income of community and government. The commodity with the largest employment was rice. However, the coconut increase the income more than other commodities because all its part can be used. If the coconut is prioritized as the main product, it is expected to give a significant economic contribution to the local economy by increasing the number of SMEs producing coconut-based goods. By doing so, it increases the income of coconut farmers as the way to reduce poverty rate asthe coconut-producing sub-districts have many poor. 


\section{Conclusion}

The result shows that the superior products of Banggai Regency are rice, corn, cassava, coconut, and banana products. The government should actively encourage the SMEs to prioritize the LSP of the coconut products. In addition, the SMEs empowerment lies in the aspects of human resource, production facilities and utilization of market potential.

\section{Acknowledgment}

This paper is part of the results of the study entitled Determining Local Superior Products Using Analytic Hierarchy Process Approach: A case study in Banggai Regency Indonesia. That the superior products of Banggai Regency are coconut products, Pelagic fish, processed food and beverage products

\section{References}

[1] BPS Kabupaten Banggai, "BPS KabupatenProduk Domestik Regional Bruto Kabupaten Banggai Menurut Lapangan Usaha 20122016," BPS Kabupaten Banggai, Banggai, 2017.

[2] BPS Kabupaten Banggai, "Banggai dalam angka," BPS Kabupaten Banggai, Banggai, 2017.

[3] BPS Kabupaten Banggai, "Indikator ekonomi Kabupaten Banggai," BPS Kabupaten Banggai, Banggai, 2017.

[4] Kementerian Perindustrian Republik Indonesia, "Analisis Perkembangan Industri Juli 2017," Pusdatin Kemenperin, Jakarta, 2017.

[5] Kementerian Perindustrian Republik Indonesia, "Laporan ekspor impor hasil pengolahan Januari dan Februari 201," Kemenperin RI, Jakarta, 2017.

[6] N. Kurniasih, P. M. Yusup and E. Kuswarno, "Empowerment of women to support family economy in Sukamukti Ciamis Indonesia," in 1st International Conference Postgraduate School Universitas Airlangga: Implementation of Climate Change Agreement to Meet Sustainable Development Goals (ICPSUAS 2017), Surabaya, 2018.

[7] N. Kurniasih, "Weblogs usage as a media promotion for Tasikmalaya handicraft," in Prosiding Simposium Kebudayaan Indonesia Malaysia (SKIM), Bandung, 2007.

[8] T. Saaty, "Decision making with the Analytic Hierarchy Process.," International Journal Services Vol 1 No. 1, pp. 83-98, 2008.

[9] Chuzaimah and Mabruroh, "Chuzaimah dan Mabruroh, 2008. Identifikasi Produk Unggulan Berbasis Ekonomi Lokal untuk Meningkatkan PAD di Era Otonomi Daerah," in Seminar Nasional Aplikasi Sains dan Teknologi 2008, IST AKPRIND, 2008.

[10] Kusdiana and Gunardi, "Pengembangan produk unggulan UMKM Kabupaten Sukabumi," Trikonomika Vol 13 No , pp. 153-171, 2014.

[11] Presiden RI, "Instruksi Presiden nomor 6 tahun 2007 tentang percepatan sektor riil dan pembangunan usaha mikro kecil dan menengah," Sekretariat Negara, Jakarta, 2007.

[12] Menteri Dalam Negeri RI, "Peraturan Menteri Dalam Negeri nomor 9 tahun 2014 tentang pedoman pengembangan produk unggulan daerah," Depdagri RI, Jakarta, 2014.

[13] Presiden RI, "Peraturan Pemerintah Nomor 17 tahun 2013 tentang PelaksanaanUndang-Undang Nomor 20 tahun 2008 tentang usaha mikro, kecil dan menengah," Sekretariat Negara RI, Jakarta, 2013.

[14] E. Armanto, N. Latifah and N. D. Susanti, "Penerapan metode AHP (Analytic Hierarchy Process) untuk menentukan kualitas gula tumbu," Jurnal SimetrisVol 5 No 1, pp. 75-82, 2014.

[15] L. P. Abdurrozzaq Hasibuan1, O. K. Sulaiman, N. Kurniasih, T. Listyorini, D. Abdullah, A. Indahingwati, K. Saddhono, R. T. Manurung, H. Nurdiyanto and M. B. N. Wajdi, "Logistic management with beer game simulation wholesaler (lead time one week)," International Journal of Pure and Applied Mathematics Volume 119, No. 16 , pp. 2611-2616, 2018.

[16] A. D. GS, A. Indahingwati, N. Kurniasih, T. Listyorini, W. Fitriani and A. P. U. Siahaan, "Planning and controlling of raw material inventory in efforts," International Journal of Pure and Applied Mathematics Volume 119, No. 17, pp. 1977-1982, 2018. 